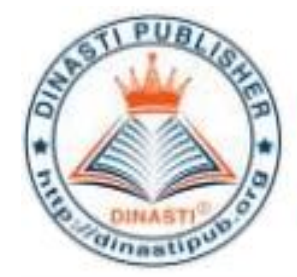

\title{
THE IMPACT PROPHET LEADERSHIP AND ORGANIZATIONAL COMMITMENT ON MOTIVATION AND ITS IMPLICATIONS ON EMPLOYEE PERFORMANCE OF THE BANK SYARIAH AL SALAAM
}

\section{Zainuri $^{1}$, Muhammad Havidz Aima ${ }^{2}$}

${ }^{1)}$ Master of Management, Mercu Buana University, Jakarta, Indonesia

${ }^{2)}$ Lecturer of Master of Management, Mercu Buana University, Jakarta, Indonesia

ARTICLE INFORMATION
Received: 27/11/2019
Revised: 29/11/2019
Issued: 05/12/2019
Corresponding author: first author
E-mail:
igho.syailendra@ gmail.com
havidz.aima@ mercubuana.ac.id

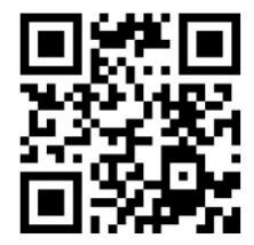

DOI:10.31933/DIJMS

\begin{abstract}
The purpose of this study is to understand and explain the impact of Prophet Leadership and organizational commitment on motivation and its implications on employee performace of the PT.Bank Syariah Al Salaam. The research method used a quantitative approach, which the population in this study was 80 employees of the Bank Syariah Al Salaam Sample selection was done by sampling technique all population 80 respondents were determined. Data collection techniques using interview and questionnaire. The questionnaire survey instrument was delivered to employees of the Bank Syariah Al Salaam. Data were analyzed by using structural equation model (SEM) with the Smart PLS3.0 software program. This study reveals that Prophet Leadership, organizational commitment and motivation have a significant positive effect on employee performance, both partially and simultaneously. Besides that, the motivation partially mediate variable of the Prophet Leadership variable and organizational commitment on employee performance and has a significant effect.
\end{abstract}

Keywords: Prophet Leadership, Organizational Commitment Motivation and Employee Performance. 


\section{INTRODUCTION}

Prophetic leadership can have an impact on increasing organizational commitment (organizational Commitment) (Mansyur,2013), as ethical leaders increase organizational pride and loyalty. In an organization, there is a possibility of not having a direct impact on increasing the commitment or performance of members of the organization when leaders are MSME (Ministry of Micro, Small and Medium Enterprises) target which in 2017 reached $54 \%$, decreased in 2017 and 2018 to $65 \%$, this achievement should be expected to increase each year. The decline in business performance, in this case, the productivity of employees in the Marketing Division in the process of marketing activities decreased each year from $70 \%$ (2016) to 60\% (2017) and 50\% (2018) this data was obtained based on direct interviews with Business Directors and Division Heads Marketing, marketing activities are routine activities carried out by employees in improving performance each year, especially in increasing the portfolio. Also, the active role of employees in upholding discipline tends to decrease in the 2017 and 2018data.

To ensure the factors that influence the performance of Bank Syariah Al Salaam employees Al Salaam is a Prophetic Leadership, Organizational Commitment, and Motivation, the authors conducted a pre-questionnaire as the pilot test that should be filled by 30 employees. Based on the pre-survey unable to emphasize their members' relationships and contributions to the success of the organization and are unable to build positive relationships with members of the organization. Organizational goals cannot be achieved if the members do not want to contribute to the achievement of organizational goals when the organization does not help members achieve their goals. Bank Syariah Al Salaam is one of the Islamic people's finance banks as one of the financial services financing institutions that applies management to prophetic leaders. Where not merely achieve a high portfolio in running its business but it balances the principles of the world and the hereafter, because it works and lives for worship. Becoming one of the pioneers of Bank Syariah in Indonesia that applies sharia principles.

Business performance is inseparable from the performance of employees sourced from human resources itself, where it is important to understand the main factors that affect employee performance compared to knowing the impact or consequences caused by the performance of the employees themselves. The managerial pattern adopted by the company has an impact on the ups and downs in sales performance received by the company within a period of 3 (three) years starting from 2016 to2018.

The achievement of Bank Syariah Al Salaam business performance has not been fully implemented and has even tended to decline in the achievements set by the company over the past three years. In carrying out the work process in 2016 amountedtoRp.6,516,152withapercentagevalueof65\% ofthe target set by the company, but in the following year there was a gradual decline. Another decrease occurred in achieving the results above, it is known that the 3 biggest factors that influence employee performance are prophetic leadership (26.7\%), organizational commitment (23.3\%), and motivation (23.3\%). Based on the information described above, the researcher needs to research the theme "The Impact Prophet Leadership and Organizational on motivation and its implications on employee performance of the Bank Syariah Al Salaam". 


\section{LITERATURE REVIEW}

\section{Prophet leadership (PL)}

In prophetic leadership, leadership opposes spiritualism, because it is attached to divine values (Zuhdi, 2004). These Apostles base their leadership on the truth that comes from Godin guiding, serving, enlightening, and making changes. The leadership of the Messengers is human as God's representative (caliph) who is given the mandate to lead and care for His earth and all its contents from damage. The meaning of the caliph in humans as leaders is implemented in leadership characters who always hold to the conscience (Zuhdi,2004).

If the focus of the study is about Prophetic Islam, leadership has two main roles namely: 1) leaders as servants, servants of society, who help the welfare of society and guide them for kindness, 2) leader as a guardian (guardian leader), Secure the community from challenges and protections that encourage the awareness of God, as well as justice, trust and integrity (Beekun and Badawi, 1999). In Prophetic, Christianal so believes that leaders are those who serve their followers (Mckechnie, 2001).

In Islamic prophetic leaders are leaders who have the nature and character of themselves included in the dimensions of the prophetic leadership variable namely Siddiq (honest integrity), trustful (trustworthy and responsible), fathanah (smart, quality, professional), tabligh (communicative and visionary) (Antonio, 2013; Budiharto and Himam, 2006) the above characteristics and characteristics are the dimensions that connect leadership performance prophetic.

\section{Organizational Commitment (OC)}

There are three dimensions of organizational commitment according to Meyer and Allen (1991), namely: 1) Affective commitment (affective commitment), refers to the emotional connection of members to the organization. People with a high level of affective commitment have a desire to remain in the organization because they support the goals of the organization and are willing to help to achieve these goals. 2) Continuous commitment refers to the desire of employees to remain in the organization because of the calculation of profit and loss where the economic value felt by surviving in an organization is compared to leaving the organization. The longer they stay with their organization, the more they are afraid of losing what they have invested in the organization. This commitment leads to the tendency of employees not to leave the organization. Investments owned by employees in the form of time, their efforts in doing work, developing friendships with colleagues, certain skills that the organization needs, and compensation that can reduce employees to other external opportunities (jaros, jermier, Koehler and sincich, 1993). Ongoing commitment occurs when an employee persists in an organizationbecause he needs a salary and other benefits because he needs to (need to) (woods et al., 2012; philipp and lopez, 2013). 3) Normative commitment (normative commitment), refers to the feelings of employees where they feel obliged to remain in the organization because they feel they have a moral responsibility to the organization. This normative commitment occurs from the employee's self values. 


\section{Motivation (MOT)}

According to Siagian (2012: 135), motivation is an activity that encourages employees or employees to support as much as possible in carrying out their duties because it is related to the achievement of the organization and its various objectives, the personal interests of the members of the organization will be maintained as well. Motivation is a variety of behaviors that are shown on target with the level of effort someone does in pursuing a particular goal. According to Thoha (2012: 177), motivation is the desire to achieve several goals or driving people to carry out activities to achieve their goals.

\section{Employee Performance (EP)}

Mangkunegara (2011: 67) defines performance (work performance) as follows: "Performance is the result of work in quality and quantity achieved by anemployee in carrying

\section{Conceptual Framework}

Nurul Qomarianing P, Arik prasetya (2016), S.Nugroho, Ganjar, AimaHavidz (2018) reveal that Leadership has a positive impact on motivation that Leadership has a positive impact on employee performance. Elizabeth Wairimu Waiyaki (2017) Ishak Runi, Mansyur Ramli (2017) reveal that leadership gives a positive impact on motivation and organizational commitment. Besides it, Other previous researches reveal that motivation has a positive impact on employee performance Elizabeth Wairimu Waiyaki (2017).

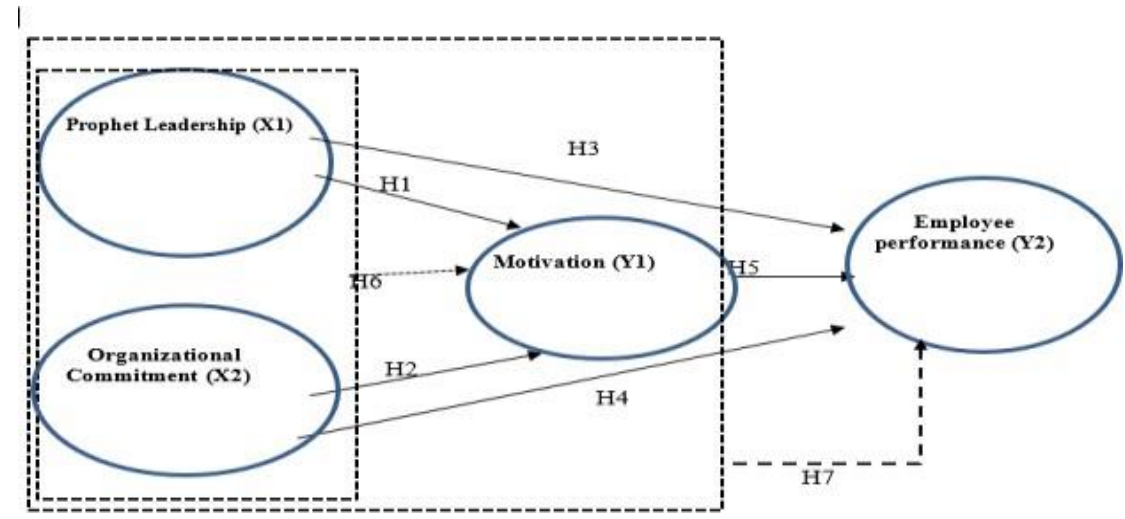

Fig. 1. Theoretical Framework Source: Theoretical Review

\section{RESEARCH METHODS}

The type of research used is quantitative research using primary data in the form of surveys. To get complete, relevant and complementary data, in addition to the primary data in the form of surveys, researchers use secondary data in the form of performance scores of Bank Syariah, the number of employee permits in 3 (two) years. This research was designed with the aim to be able to understand, explain and analyze the correlation between independent variables on the dependent variable. The details of the variable are measured through dimension and indicator. The number of items is provided in figure 2. The independent variable (exogenous) that measured by Likert scale are Prophet leadership (X1) and Organizational Commitment (X2), while the dependent variable (endogenous) are Motivation (Y1) as well as mediation variable and Employee Performance (Y2). 


\begin{tabular}{|c|c|}
\hline Varlable & DImenslon \\
\hline Prophet Leacership $(X 1)$ & 1. Sinvodong (Loyaind, Integrity) \\
\hline & 2. A.manah (Trust, responsibie) \\
\hline & 3. TaOUghn (conveying, good delver) \\
\hline & 1. Fathona/h (Inrenegence) \\
\hline Organisafional Commentment & 1 Crmmutmen Afekthif \\
\hline & 2) Commutment Cotinyusutas: \\
\hline & .8 Cammitmen Ninmatif \\
\hline Motivation & 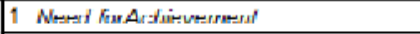 \\
\hline & 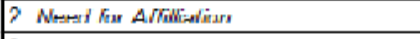 \\
\hline Employee Performance & $\begin{array}{l}\text { 3. Nevd fur Puwer } \\
\text { 1. Work quality } \\
\text { 2. The nesrith of work quiality }\end{array}$ \\
\hline & 3 Teamwork \\
\hline & 4. Responsible \\
\hline
\end{tabular}

Figure 2. Table Variable Measurement

\section{Population and Sample}

In this study using the entire population, namely all employees of Bank Syariah Al Salaam as many as 80 people or by using a saturated sample.

This research applied the analysis data techniques by utilizing SmartPLS version 3.2.7 and being run by computer. Partial Least Square (PLS) as structural equation model (SEM) analysis by using its variant simultaneously to test measurement model as well as structural model. Measurement model is utilized to run validity and reliability test, while structural model is utilized to run causality test (hypotheses test my using prediction model). Through PLS approach, it assumes that all the variances could be used to explain the data analysis technique in the research and it is divided into two, such as:

1) Descriptive statistical analysis is an empirical analysis that describe any information that obtained to figure or explain certain cases (who/what, when, where, how, and how many) and it is collected in the research (Supranto:2012). Those data are from the respondents' answers for the items on the questionnaire.

2) Researchers will process the acquired data by separating it into categories, do the tabulation and explain afterwards.

3) Inferential statistical analysis is a statistic technique that will be used to analyze data sample and the results will be used for the population (Sugiyono:2009). Along with the hypotheses, thus the inferential statistic data analysis in this research will be using SmartPLS software (Partial Least Square) for its outer model, inner model and hypotheses measurements

\section{FINDINGS AND DISCUSSION}

\section{Findings}

Data analysis results are prepared descriptively from each obtained variable. This research acquired 80 employee respondents of Bank Syariah Al Salman. Based on the results, there are 38 female employees with the percentage for $47.5 \%$, while 42 male employees with the percentage for $52.5 \%$. Based on the education background, there 23 employees senior high school with $28.75 \%$, there are 15 employees with $18.75 \%$ who acquired D3, 42 employeesor $52.5 \%$ who acquired S1. Additionally, based on working experience, the highest number is with atenure of more than 10 years, which is equal to 40 employees. 
Descriptive statistic analysis is used to understand the tendency of questionnaire's answer or how far the response of respondents based on the category choices by usinglike scale from the scale of 1 (totally disagree) until 5 (totally agree) for each statement of variables. Based on the collected data, it is then tabulated to know the answer's distribution from each indicator for each research variable and the results indicates as follows:

1) Prophet Leadership variables have an average of 4.07. This shows in general that the Prophet Leadership felt by Bank Syariah AL Salaam employees is sufficient in accordance with the tasks and functions but can still be improved again.

2) Organizational Commitment variable has an average of 3.27. This shows in general that the role of Organizational Commitment felt by employees of the Bank Syariah is sufficient but still needs to be improved so that employees are more prosperous and have a positive impact on the organization.

3) Motivation variables have an average of 3.43.This shows that the motivation of the employees of the Bank Syariah AL Salaam is quite good but needs to be improved.

4) Performance employee variables have an average value of 3.36. This shows that the performance of the Bank Syariah AL Salaam employees has not been good or that the average is good enough so that it needs to be improvedagain.

The measurement of evaluation model (outer model) is executed to understand the validity and reliability that connect among indicators with the latent variable. Convergent validity test is executed by investigating the reliability of individual item, internal consistency, or construct reliability, and average variance extracted. Convergent validity evaluation from the investigation of individual item reliability could be measured from the value of standardized loading factor. Standardized loading factor assesses the correlation between each item of indicator with its construct. Loading factor value that applied in this research is $>0.5$, hence if the loading factor value is $<0.5$ on the calculation model result (outermodel) it will be excluded from the model, and the results is all Indicator from each workload variable, compensation variable, motivation variable and employee performance variable indicates loading factor value for $>0.50$. This result revealed that all indicator are valid and will be used in this research or are not being excluded from themodel.

Convergent validity evaluation from the investigation of Average Variance Extracted (AVE) describe the amount of variant or variant of manifest variable that could be possessed by its latent construct. The greater variant of manifest variable that could be possessed by its latent construct, the greater representation of manifest variable to the latent construct. Convergent validity evaluation from the investigation of Average Variance Extracted (AVE) could be measured from its AVE value based on the data tabulation with SmartPLS version 3.2.7.

Table 1. The Mean Value of Average Variance Extracted (AVE) for Each Variable

\begin{tabular}{cc}
\hline Variable & Score of Average Variance Extracted (AVE) \\
\hline Prophet Leadership & 0.769 \\
\hline Organizational Commitment & 0.768 \\
\hline Motivation & 0.788 \\
\hline Employee Performance & 0.709 \\
\hline
\end{tabular}


Based on the table above, it reveals that all the variables have > 0.50 of AVE value. Convergent validity evaluation from the investigation of internal consistency reliability could be measured from the value of Cronbach's Coefficient Alpha and Composite Reliability (CR) that provided on table below. The table provided is a result of Smart PLS version 3.2.7.

Table 2. Crobach's Coefficient Alpha and Composite Reliability (CR) Value

\begin{tabular}{ccc}
\hline Variable & $\begin{array}{c}\text { Cronbach's } \\
\text { Coefficient } \\
\text { Alpha }\end{array}$ & $\begin{array}{c}\text { Composite } \\
\text { Real (CR) }\end{array}$ \\
\hline Prophet Leadership & 0.965 & 0.970 \\
\hline $\begin{array}{c}\text { Organizational } \\
\text { Commitment }\end{array}$ & 0.968 & 0.974 \\
\hline Motivation & 0.953 & 0.962 \\
\hline Employee performance & 0.965 & 0.968 \\
\hline
\end{tabular}

Based on table above, it reveals the value of Cronbach's Coefficient Alpha for Prophet Leadership, Organizational Commitment, Motivation, and Employee performance more than 0.6 or even close to 1 and its Composite Reliability (CR) value is more than 0.7. This value is more than the standard, each of it are> 0.6 and > 0.7 , and hence all the variables in this research are reliable. For the structural model evaluation (inner model) or hypothesis test in this research is proceed on several steps, such as evaluating path coefficient value, R2value evaluation, effect size $\mathrm{f} 2$ measurement, validate the entire structural model by using Goodness of Fit Index (GoF), as well as execute predictive relevance test (Q2). Meanwhile, based onSmartPLSversion3.2.7calculationusingbootstrappingand it reveals the result for path coefficient that explain the relationship between construct/variable as shown on table below:

Table 3. Path Coefficient (CR)

\begin{tabular}{lllc}
\hline & $\begin{array}{l}\text { Original } \\
\text { Sample (O) }\end{array}$ & $\begin{array}{l}\text { T Statistic } \\
\text { (O/STDEV) }\end{array}$ & P Values \\
\hline $\begin{array}{l}\text { Prophet Leadership (x1) -> } \\
\text { Motivation (y1) }\end{array}$ & 0.422 & 3.261 & 0.001 \\
$\begin{array}{l}\text { Prophet Leadership (x1) -> } \\
\text { Employee Performance (y2) }\end{array}$ & 0.298 & 3.071 & 0.002 \\
\hline $\begin{array}{l}\text { Organizational Commitment (x2) - } \\
\text { Motivation (y1) }\end{array}$ & 0.438 & 3.415 & 0.001 \\
\hline $\begin{array}{l}\text { Organizational Commitment (x2) } \\
->\text { Employee Performance (y2) }\end{array}$ & 0.454 & 4.668 & 0.000 \\
\hline $\begin{array}{l}\text { Motivation (y1) -> Employee } \\
\text { Performance (y2) }\end{array}$ & 0.235 & 3.010 & 0.003 \\
\hline
\end{tabular}

Simultaneous influence of prophet leadership and Organizational Commitment to Motivation (MOT) could be measured through $\mathrm{f}$ statistic by using the equation: 
a. $\mathrm{R}=0.680(\mathrm{MOT})$

$$
\begin{aligned}
\mathrm{F}_{\text {hitung }} 1 & =\frac{\frac{R^{2}}{(k-1)}}{\frac{1-R^{2}}{(n-k)}} \\
& =\frac{\frac{0.680}{(4-1)}}{\frac{1-0.680}{80-4}} \\
& =53.81
\end{aligned}
$$

The simultaneous effect of Prophet Leadership variables Organizational Commitment and motivation on employee performance (EP) can be done by statistical $\mathrm{f} /$ statistical statistics using the formula below.

b. $\mathrm{R}=0.856(\mathrm{EP})$

$$
\begin{aligned}
\mathrm{F}_{\text {hitung }} 1 & =\frac{\frac{R^{2}}{(k-1)}}{\frac{1-R^{2}}{(n-k)}} \\
& =\frac{\frac{0.856}{(4-1)}}{\frac{1-0.856}{(80-4)}} \\
& =150.6
\end{aligned}
$$

To evaluate the value of R2 based on the calculation results using calculate SmartPLS version 3.0 algorithm, the $\mathrm{R} 2$ value is 0.680 for the motivation variable and 0.856 for the performance variable. The value of $\mathrm{R} 2$ shows that the level of determination of exogenous variables (Prophet leadership and organizational commitment) towards the endogenous is quite high.

Significant test results are simultaneously used to test hypotheses 6 and 7 in this study. The value of the F statistic in this study is 53.81 and $150.6 \mathrm{~F}$ table values at alpha 0.05 are 2.70. This means f statistic> f Table (2.70), then H6 and $\mathrm{H} 7$ are accepted.

Effect size f 2 measurement is also conducted to know the impact of exogeneous variable to endogen variable or to know the model fitness. The value for 0.02 indicates has weak impact, 0.15 has moderate impact, and 0.35 has strong impact. The results of effect size value (f square) are: 1) f square value of prophet leadership to motivation is 0.168 . It reveals that prophet leadership has moderate impact on the structural level; 2) f square value of organizational commitment on motivation is 0.181 that proved a moderate impact to the structural level; 3) f square value of prophet leadership to employee performance is 0.159 that proved a moderate impact of prophet leadership to the structutallevel;4) f square value of organizational commitment on employee performance is 0.365 that reveals strong impact of compensation to the structural level; 5) f square of motivation to employee performance is 0.123 that reveals a weak impact of motivation to the structural level.

To validate the entire structural model with Goodness of Fit index (GoF) is to validate the composite performance of outer model and inner model that obtained from the calculation as follows:

$$
\begin{aligned}
& \mathrm{GoF}=\sqrt{ } \mathrm{AVE} \times \mathrm{R}^{2} ; \mathrm{GoF}=\sqrt{ } 0.75 \times 0.291 ; \mathrm{GoF}=\sqrt{ } 0.218 \\
& \mathrm{GoF}=0.466
\end{aligned}
$$


Where: $\mathrm{AVE}($ mean AVE for entire variable $)=0.75 ; \mathrm{R}$ Square $=(0.60 \times 0.856) / 2=0.291$

Concluded that both models are very good since the value of GoF is greater than 0.36 (large scale of GoF). Besides, predictive relevance (Q2 ) test is also being tested to validate the model with the results as follows:

$$
\begin{aligned}
& \mathrm{Q} 2=1-(1-\mathrm{R} 12)(1-\mathrm{R} 22) ; \mathrm{Q} 2=1-(1-0,680)(1-0,856) ; \\
& \mathrm{Q} 2=0.954
\end{aligned}
$$

The result reveals that Q 2 value is 0.954 . In this research model, the endogenous variable has Q2 value that greater than 0 (zero) and hence its exogeneous variable could predict the endogenous variables in which organizational commitment. On the other words, this proves the model has quite better predictive relevance.

Hypotheses test about the impact of exogeneous variable; prophet leadership( $(\xi 1)$,organizational commitment $(\xi 2)$ to the endogenous variable of motivation $(\eta 1)$ both partially and simultaneously as well as prophet leadership $(\xi 1)$, organizational commitment $(\xi 2)$, and motivation $(\eta 1)$ to the endogenous variable of employee performance $(\eta 2)$, and the following content is regarding the effect of mediator or mediator effect of motivation.

\begin{tabular}{|c|c|c|c|}
\hline & $\mathrm{T}$ Statistic (O/STDEV) & T Tabel & PValues \\
\hline $\begin{array}{l}\text { Prophet Leadership (x1) -> } \\
\text { Motivation (y1) }\end{array}$ & 3.261 & 1.662 & 0.001 \\
\hline $\begin{array}{l}\text { Prophet Leadership (x1) - } \\
>\text { Employee Performance (y2) }\end{array}$ & 3.071 & 1.662 & 0.002 \\
\hline $\begin{array}{l}\text { Organizational Commitment } \\
\text { (x2) -> Motivation (y1) }\end{array}$ & 3.415 & 1.662 & 0.001 \\
\hline $\begin{array}{l}\text { Organizational Commitment } \\
\text { (x2) -> Employee } \\
\text { Performance (y2) }\end{array}$ & 4.668 & 1.662 & 0.000 \\
\hline $\begin{array}{l}\text { Motivation (y1) -> Employee } \\
\text { Performance (y2) }\end{array}$ & 3010 & 1.662 & 0.003 \\
\hline
\end{tabular}

Table 4. The Impact of Independent Variables to the Dependent variables partially

\begin{tabular}{|c|c|c|c|c|c|}
\hline & R square & F Statistic & F Table & Alpha & Result \\
\hline$(\mathrm{PL}, \mathrm{OC})->\mathrm{MOT}$ & 0.680 & 53.81 & 2.7 & 0.05 & $\begin{array}{c}\text { F Stat > F Table } \\
\text { (H6 accepted) }\end{array}$ \\
\hline $\begin{array}{c}(\mathrm{PL}, \mathrm{OC}, \mathrm{MOT}) \\
->\mathrm{EP}\end{array}$ & 0.856 & 150.6 & 2.7 & 0.05 & $\begin{array}{c}\text { F Stas > F Table } \\
(\text { H7 accepted })\end{array}$ \\
\hline
\end{tabular}

Table 5. R2 Evaluation and F Statistic Test Source: Smart PLS version 3.2.8 
Table 6. Indirect effect (indirect effect) independent variables against dependent variables

\begin{tabular}{ccccc}
\hline & $\begin{array}{c}\text { Original } \\
\text { Sample (O) }\end{array}$ & $\begin{array}{c}\text { T-Statistic } \\
\text { (O/STDEV) }\end{array}$ & T Table & P-Value \\
\hline $\begin{array}{c}\text { Prophet leadership (x1) -> Motivation } \\
\text { (y1) -> Employee Performance (y2) }\end{array}$ & 0.099 & 2.165 & 1.662 & 0.031 \\
\hline $\begin{array}{c}\text { Organizational commitment (x2) -> } \\
\text { Motivation (y1) -> Employee } \\
\text { Performance (y2) }\end{array}$ & 0.103 & 3.147 & 1.662 & 0.002 \\
\hline
\end{tabular}

The statistic results are provided on the table above for structural model with the Hypothesis as follows:

1) Hypothesis 1 - Prophet leadership (PL) has effect to the Motivation. Path coefficient obtained for 0.422 and $p$ value for 0.001 . Thus, H1 is accepted $(\mathrm{p}<0.05)$ which means that prophet leadership has significant effect to the Motivation (MOT);

2) Hypothesis 2 - Organizational Commitment (OC) has effect to the Motivation (MOT). Path coefficient is obtained for 0.438 and $\mathrm{p}$ value for 0.001 . Thus, $\mathrm{H} 2$ is accepted ( $\mathrm{p}<$ 0.05 ) and it proves that Organizational commitment has positive effect and significant to the Motivation;

3) Hypothesis 3 - Prophet leadership (PL) has effect to the employee performance (EP) and the path coefficient is obtained for 0.298 with the $p$ value for 0.002 . Therefore, H3 is accepted $(\mathrm{p}<0.05)$. prophet leadership (PL) has significant effect to the employee performance (EP);

4) Hypothesis4 - Organizational Commitment (OC) has effect to the employee performance (EP) 0.454 is obtained for the path coefficient with the $p$ value for 0.000 . T-Statistic is 6.377 and P-Values is 0.000. Hence, $\mathrm{H} 4$ is accepted $(\mathrm{p}<0.05)$, it means that organizational commitment (OC) has significant effect to the employee performance $(\mathrm{EP})$

5) Hypothesis 5 - Motivation (MOT) has effect to the Employee Performance (EP) and the path coefficient is obtained for 0.235 with the $p$ value for 0.003 . Therefore, H5 is accepted $(p<0.05)$. Motivation has significant effect to the employee performance;

6) Hypothesis 6 - prophet leadership (PL) and Organizational commitment (OC) has effect to the Motivation (MOT). These variables have (R2) for 0.680 . With $\mathrm{f}$ statistic value 53.81 and $\mathrm{f}$ table on alpha 0.05 is 2.7 . This result indicates that $\mathrm{f}$ statistic (53.81) $>\mathrm{f}$ table (2.70), hence H6 is accepted and HO is rejected. In short, it could be concluded that hypothesis 6 is proved as prophet leadership and organizational commitment have positive effect and significant to the motivation;

7) Hypothesis 7 - prophet leadership (PL), organizational commitment (OC) and Motivation (MOT) have effect to the employee performance. The (R2) value for prophet leadership (PL), organizational commitment (OC), and motivation (MOT) is 0.856 with the $\mathrm{f}$ statistic for 150.6 and $\mathrm{f}$ table of alpha for 0.05 is 2.70 . The result reveals that $\mathrm{f}$ statistic 
(150.6 > f table 2.70) hence H7 is accepted and HO is rejected. In the other word, it proves that prophet leadership (PL), organizational commitment (OC) and motivation (MOT) have significant effect to the employee performance;

8) Hypothesis 8 - path coefficient hypothesis between prophet leadership or organizational commitment and employee performance from direct effect to indirect effect, the value drop, then HO is accepted and H8 is rejected. prophetic on performance 0.298> path coefficient value indirect influence of aesthetic leadership on performance is 0.099 then prophetic leadership on performance is not mediated by motivation variables and path coefficient values the direct influence of organizational commitment on performance 0.454> path coefficient values indirect influence of organizational commitment to performance is 0.103 then compensation for performance is not mediated by motivational variables.

From Tables above it can be concluded as follows:

1) On the prophetic leadership variable on the motivational variable, the highest correlation dimension is shiddiq on the dimension of the need for achievement, amounting to 0.719 . While the lowest correlation dimension on this variable is the fathonah to motivational dimensions, which is- 0.048 .

Based on the description above it can be seen that Shiddiq is the right direction for employees to create a condition that a good leader is always a good example.

2) In the prophetic leadership variable on the performance variable, the highest dimension change is the safe dimension of prophetic leadership to the dimensions of work quality, amounting to 0.422 . While the lowest dimension in this variable is the fatonah dimension towards the cooperation dimension, which is-0.049. Based on the description above, it can be seen again that ammana is the nature of a leader who has a great influence on the quality and even employee performance.

3) On the variable organizational commitment to the motivational variable, the most important dimension is the direct continuity commitment to the motivational dimension, amounting to 0.824 . While the lowest dimension of this variable is the affective dimension that is not directly related to motivation, which is -0.234 .

4) On the variable organizational commitment to the performance variable, the highest correlation dimension is the direct normative commitment to the dimensions of work quality, amounting to 0.816 . Based on the description above, it can be seen that normative commitment is a commitment that can foster a sense of sacrifice or loyalty to the company, and place it as a commitment with the highest value meaning that every employee who feels comfortable in the company will automatically produce better performance.

5) On the motivation variable on the performance variable, the highest correlation dimension is the need for achievement on the responsibility dimension, amounting to 0.815 . Based on the description above that the need for appreciation or achievement for each employee given to each individual is very influential in producing better performance and responsibilities towards work. 


\section{Matrix Correlation}

Result matrix correlation dimension variables independent and dependent variables below:

\begin{tabular}{|c|c|c|c|c|c|c|c|c|}
\hline \multirow{2}{*}{ Variabel } & \multirow{2}{*}{ Dimensi } & \multicolumn{3}{|c|}{ Motivation(Y1) } & \multicolumn{4}{|c|}{ Employee Performance (Y2) } \\
\hline & & Y1.1 & Y1.2 & Y1.3 & Y 2.1 & Y2.2 & Y2.3 & Y2.4 \\
\hline \multirow{4}{*}{$\begin{array}{l}\text { Prophet Leadership } \\
\text { (X1) }\end{array}$} & Shidd iq & 0,719 & 0,634 & 1,312 & -0.023 & 0.333 & 0,063 & 0,126 \\
\hline & Ammanah & 0.391 & 0.197 & 0,270 & 0.278 & 0.159 & 0,422 & 0,173 \\
\hline & Tabligh & -0.548 & -0.401 & $-0,932$ & -0.206 & -0.173 & 0,037 & $-0,206$ \\
\hline & Fathonah & 0,021 & -0.048 & $-0,291$ & 0,081 & 0,166 & $-0,049$ & 0,268 \\
\hline \multirow{3}{*}{$\begin{array}{c}\text { Organizational } \\
\text { Commitment (X2) }\end{array}$} & commitment Afektif & $-0,234$ & -0.272 & $-0,760$ & -0.140 & 0,402 & 0,299 & 0.655 \\
\hline & $\begin{array}{l}\text { Commitment } \\
\text { continyuitas }\end{array}$ & 0,548 & 0.422 & 0,824 & 0.126 & 0,204 & 0,028 & 0.115 \\
\hline & Commitment Normatif & 0,012 & 0,350 & 0.251 & 0.816 & -0.138 & 0,090 & $-0,200$ \\
\hline \multirow{3}{*}{ Motivasi (Y1) } & Need for achievement & 0,597 & 0,727 & 0,784 & 0,815 & & & \\
\hline & Need for aviliasi & 0.473 & 0.285 & 0,271 & 0,341 & & & \\
\hline & Need for power & $-0,313$ & $-0,154$ & $-0,282$ & $-0,374$ & & & \\
\hline
\end{tabular}

Figure 3. Result matrix correlation dimension variables independent and dependent variables

Based on the description above, it can be seen that commitment is the most important thing for employee resilience. One of the commitments is continuity, providing sustainable direction or motivation for all employees. So that if each party is committed well and sustainably, employees will feel comfortable in working

\section{Discussion}

The influence of each research variable is related to the theory and a review of previous research can be explained in a discussion of the results of the research in detail as follows:

1) Effect of Prophetic Leadership (PL) on Motivation (MOT) (Hypothesis 1)

The $\mathrm{p}$-value of the prophetic motivation variable toward work motivation (PL $\rightarrow$ MOT) is significant with a p-value of 0.001 , T statistic of 3.261 and the original sample is positive. Because the p-value obtained is significant, $T$ statistic $>1.662$ and the original sample is positive then Ho is rejected and it is concluded that prophetic leadership has a positive and significant effect on work motivation, the more in line with expectations and close to employees, prophetic leadership the higher the work motivation employee and vice versa.

Every sharia financial institution certainly has a sharia- compliant culture as well as the Al-Salaam SRB which has a prophetic leader who is certainly a good example and 
example for all his employees. Not merely carrying out business activities but also balancing worship in carrying out its activities. As stated in Surah Al-Hajj: 58 means "and God is the best giver of sustenance".

This condition is relevant to the conditions of employees at Bank Syariah Al Salaam where the employees respect each other by prioritizing common interests by accepting the directives of the main leadership of course following Islamic rules.

This is reinforced by the research of Ganjar Satrio Nugroho, Aima Havidz (2018). Fina Firdayanti (2019) which shows the results that leadership has a positive and significant influence on work motivation.

\section{2) Effect of Organizational Commitment / OC Commitment on Motivation / MOT} (hypothesis 2)

The p-value of the influence of organizational commitment variable on work motivation $(\mathrm{OC} \rightarrow \mathrm{MOT})$ is significant with p-value of 0.001 , T statistic of 3.415 and the original sample is positive. Because the p-value obtained is significant, $\mathrm{T}$ statistic $>1.662$ and the original sample is positive then Ho is rejected and it is concluded that compensation has a positive and significant effect on work motivation, the greater organizational commitment the company gives to employees, the higher employee motivation.

Ishak Runi, Mansyur Ramli (2017) suggested that organizational commitment is a form of attitude towards one's behavior towards the organization in the form of loyalty and achievement of organizational goals.

Based on the opinion above, it can be indicated that there is an influence of organizational commitment on motivation. This is reinforced by the research of Mansyur Ramli (2017) and Mafizatun N (2018) which shows the results that organizational commitment has a positive and significant influence on work motivation.

3) Effect of Prophetic leadership (PL) on employee Performance / EP (hypothesis 3)

The $p$-value of the influence of the prophetic leadership variable on performance (PL $\rightarrow$ EP) is significant with p-value of 0.002 , T statistic of 3.071 and the original sample is positive. Because the $\mathrm{p}$-value obtained is significant, T statistic $>1.662$ and the original sample is positive then Ho is rejected and it is concluded that prophetic leadership has a positive and significant effect on performance, the more in line with the prophetic leadership pattern according to employee expectations, the higher the employee performance, so the opposite. In Islamic prophetic leaders are leaders who have the nature and character of themselves namely siddiq (honest integrity), trustful (trustworthy and responsible), fathanah (intelligent, quality, professional), tabligh (communicative and visionary) (Antonio, 2013; Budiharto and Himam, 2006).

Mafizatun N (2018) states that prophetic leadership has a positive effect on job satisfaction, also expressed by Sri Arha Lestari (2016) that leadership has a positive effect on employee performance and job satisfaction. High prophetic leadership makes every employee comfortable at work to create loyalty and automatically work happily with no burden on each person to understand their duties and responsibilities. This is what makes employee performance increasingly work with heart, trust, and responsibility. 


\section{4) Effect of Organizational Commitment /OC Commitment on employee Performance} / EP (hypothesis 4)

The p-value of the effect of the compensation variable on performance (OC $\rightarrow \mathrm{EP})$ is significant with a p-value of $0,000, \mathrm{~T}$ statistic of 4.668 and the original sample is positive. Because the p-value obtained is significant, T statistic $>1.662$ and the original sample is positive then Ho is rejected and it is concluded that organizational commitment has a positive and significant effect on employee performance, the greater organizational commitment the company gives to employees, the higher employee performance, so the opposite.

Organizational commitment is a form of attitude towards one's behavior towards the organization in the form of loyalty and achievement of organizational goals. Organizational commitment is the most important thing that must be considered by an organization or company in increasing an increase in employee satisfaction whose output is increasing employee performance. This organizational commitment can increase or decrease employee performance and must be the focus of the company. If the commitment is felt to be unfair, it will cause disappointment to the employees, so that good employees will leave the company. According to Hasibuan in Kadarisman (2012: 86) is "As a bond of cooperation, job satisfaction, effective procurement, motivation, employee stability, and discipline".

Based on these theoretical studies, it can be indicated that there is a relationship between organizational commitment and employee performance. This is supported by the results of research conducted by Ishak Runi, Mansyur Ramli (2017) which shows that there is a positive and significant influence between organizational commitment and employee performance.

\section{5) Effect of Motivation / MOT on Employee Performance / EP (hypothesis 5)}

The p-value of the influence of the motivation variable on performance (MOT $\rightarrow$ EP) is significant with a p-value of 0.003 , the $\mathrm{T}$ statistic is 3.010 and the original sample is positive. Because the $\mathrm{p}$-value obtained is significant, T statistic $>1.662$ and the original sample is positive then Ho is rejected and it is concluded that motivation has a positive and significant effect on performance, the higher employee motivation, the higher employee performance, and vice versa.

McClelland in Mangkunegara (2011: 104) concluded that "There is a positive relationship between work motivation and employee performance, where if a manager or leader who has high work motivation tends to have high performance, and conversely those with low performance are possible because of low work motivation"

Based on the theoretical study above, it can be indicated that there is a significant influence between motivation and employee performance. This is reinforced by the results of research conducted by Kusuma Wardhani (2017), and Randy DP, Aima Havidz (2018) which show that there is a positive and significant influence between motivation and employee performance. 
6) Effect of Prophetic Leadership / PL and Organizational Commitment / OC on Motivation / MOT (hypothesis 6)

$R 2$ value of motivation variable is 0,680 with $F$ count 53,81 because $F$ count value> $F$ table (2.70), it is concluded that the prophetic leadership variable and organizational commitment simultaneously have a significant effect on motivation variable with the influence of simultaneous by $68 \%$, while the remaining $32 \%$ motivation of employees of Bank Syariah AL Salaam is influenced by other factors beyond prophetic leadership and organizational commitment.

Assumptions are the interrelationships between prophetic leadership variables, organizational commitment, and motivation together on employee performance. Based on the results of the research that has been informed above, each variable has a positive influence in influencing employee performance. For this reason, a temporary conclusion can be drawn that each variable, namely prophetic leadership, organizational commitment and motivation for employee performance will be further investigated.

7) Effects of Prophetic Leadership / PL Organizational Commitment / OC , and Motivation / MOT on Employee Performance / EP (hypothesis 7)

$\mathrm{R}$ square value of the performance variable is 0.856 with an $\mathrm{F}$ count of 150.6 , because the value of $\mathrm{F}$ arithmetic $>\mathrm{F}$ table it can be concluded that the variables of motivation, prophetic leadership, and organizational commitment simultaneously have a significant effect on the motivation variable with a large simultaneous effect of $85.6 \%$, this shows that $85.6 \%$ of the variants of Bank Syariah Al Salaam is influenced by prophetic leadership, organizational commitment, and motivation, while the remaining $14.4 \%$ of the performance of Bank Syariah AL Salaam employees is influenced by factors outside prophetic leadership, organizational commitment, and employee motivation.

Assuming there is a link between prophetic leadership variables and organizational commitment together to motivation. Based on the results of the research which have been stated above, each variable has a positive influence on influencing work motivation. For this reason, a temporary conclusion can be drawn that each variable, namely prophetic leadership, and organizational commitment, together has a positive effect on work motivation that will be further investigated.

8) Motivation Mediates Prophetic Leadership / PL and Organizational Commitment / OC towards Performance / EPK (hypothesis 8)

The path coefficient value of the direct influence of prophetic leadership on performance $0.298>$ the value of the path coefficient of indirect influence of aesthetic leadership on performance is 0.099 then the prophetic leadership on performance is not mediated by motivation variables and the path coefficient value of the direct influence of organizational commitment to performance $0.454>$ value of the path coefficient of influence is not direct organizational commitment to performance is 0.103 , compensation for performance is not mediated by motivational variables.

Based on the above theoretical studies, it can be indicated that motivation does not mediate prophetic leadership and organizational commitment to performance. This is not in accordance with the results of research conducted by Nurul Qomarianing P (2016) 
which shows that motivation is able to mediate organizational commitment variables, compensation for performance variables

\section{CONCLUSION AND SUGESTION}

\section{Conclusion}

Based on the results of the research and discussion in the previous chapters, several conclusions can be made as follows:

1) Prophetic leadership has a significant positive effect on motivation, with the dimension of shiddiq having the strongest influence.

2) Organizational commitment has a significant positive effect on motivation, with the most influential dimensions of affective commitment.

3) Prophetic leadership has a significant positive effect on performance, with the most powerful shiddiq dimensions.

4) Organizational commitment has a significant positive effect on performance, with the most influential dimensions of affective commitment.

5) Motivation as a mediator in this study has a significant effect on performance.

6) Prophetic leadership and organizational commitment together have a significant positive effect on motivation.

7) Prophetic leadership, organizational commitment, and motivation simultaneously have a positive and significant influence on performance. Motivation does not mediate prophetic leadership and organizational commitment to performance.

\section{Suggestion}

Based on the results of the analysis of the discussion and some of the conclusions above, the suggestions that can be given to complete the results of this study are as follows:

1) For Agencies

The results of correlation analysis between dimensions show that Shiddiq, the need for achievement significantly influences motivation such as transparency of information given the delivery of the company's vision and mission to employees. so the Agency needs to do the following:

1) Capacity building programs need to be made inwhich there are a mind management and motivationprogram foremployeestobemoreresilienttojobswithpriority scale, proper planning, and fastcompletion.

2) To synchronize organizational cultural values, especially professional values, which are revealed to be the work culture of employees so that employees are accustomed to that culture to create value in each employee.

3) Company management needs to open up so that employees do not hesitate in providing input for company improvement.

4) A motivational program needs to be made in the form of clear rewards and furnishing to spur employees to growandthenthisprogramiscarriedoutroutinelyfor employees who aim to foster more enthusiasm for work from within theemployee 
2) For Further Researcher

The author hopes that further research can take on different research objects or other Islamic financial institutions or organizations with a broader scope, especially from their leaders and dig deeper into the variables that affect employee performance with a wider range of samples. The results found in the form of motivation does not mediate employee performance opens up the possibility of the influence of other variables as a mediator that can affect employee performance.

\section{REFERENCES}

Allen and Meyer. (2011). The measurement and Antecedents of Affective, Continuance and Normative Commitment to Organization. PT Elex Media Komputindo, Jakarta

Antonio, Budiharto dan Himam. (2007). Muhammad SAW: The Super leader manager. Jakarta: proLmcente.

D Pranaputra, Randy, Aima Havidz (2019). Pengaruh Beban Kerja Dan Kompensasi Terhadap Motivasi serta Implementasinya Terhadap Kinerja Pegawai Direktorat Kominfo. Tesis. UniversitasMercuBuana.Jakarta

S Nugroho, Aima Havidz (2019). Pegaruh Kepemimpinan Transpormational dan Kompensasi terhadap motivasi serta implementasinya terhadap kinerja karyawan PT. X. Tesis. Universitas MercuBuana .Jakarta.

Fridayanti, Fina (2018). Pengaruh KepemimpinanT ranspormasional dan Kompensasi Terhadap Motivasi Kerja serta Implementasinya pada Kinerja Guru SMK. Tesis. Universitas Mercu Buana. Jakarta.

Hasibuan, Malayu. (2012). Manajemen Sumber Daya Manusia. PT. Bumi Aksara. Jakarta.

Ibrahim, Masud. (2015). Impact of Motivation on Employee Performance the case of same selected micro finance companies in graha international journal of economics, commerce and management united kingdom, Vol.III.Issue II.

Ishak Runi dan Mansyur Ramli (2017). Pengaruh disiplin, komitmen, motivasi terhadap kinerja pegawai pada kantor vessel traffic makassar, Sulawesi selatan. IQSR Journal of business and management (IQSR-JBM) Vol.19,N0.7.

M. Zuhdi (2014) Kepemimpinan Transpormational Prof etik. Prenadamedia Group.Jakarta.

Nurhayati Mafizatun (2018). Analis Pengaruh Kepemimpinan Profetik terhadap Komitmen Organisasi dengan dimediasi oleh kepercayaan organisasi dan persepsi politik organisasi, studi kasus pada pengurus Nahdatul Ulama DKI Jakarta. Disertasi. Universitas Brawijaya. Malang.

Mangkuprawira, S. (2014). Manajemen Sumber Daya Manusia Strategik.Cet.2Ed.2.Penerbit Ghalia Indonesia. Jakarta.

Mangkunegara, Anwar Prabu (2015). Manajemen Sumber Daya Perusahaan. Bandung :Remaja Rosdakarya.

Rivai Zainal, Veithzal. (2014). Kepemimpinan dan Perilaku Organisasi. Raja Grafindo Persada, Jakarta.

Rivai, Veithzal dan Ella Sagala. (2013). Manajemen Sumber Daya Manusia untuk Perusahaan, PT. Rajawali Pers.Jakarta. 
Thoha, Mifta. (2014). Perilaku Organisasi: Konsep Dasar dan Aplikasinya. Rajawali Pers.Jakarta.

Qomari aning P Hidayah, Nurul (2016). Pengaruh Komitmen Organisasi terhadap kinerja karyawan melalui motivasi sebagai variable intervening pada karyawan bagian keuangan dan akuntansi Universitas Negeri Yogyakarya. Skripsi. Universitas Negeri Yogyakarta. Yogyakarta.

Wardani, Kusuma. (2017) Analis pengaruh kinerja dan motivasi terhadap kinerja karyawan biro administrasi. Tesis. Universitas Sanata Dharma.

Waiyaki, Elizabeth Wairimu. (2017). Effect of Motivation on employee performance: a case of pam golding properties limited Nairobi. Tesis. United States International University.Africa.

Yukl, Garry. (2010). Kepemimpinan dalam Organisasi. Edisi Kelima. Jakarta: PT. Indeks. 